\title{
FOREST MANAGEMENT FOR THE CONSERVATION OF Araucaria angustifolia IN SOUTHERN BRAZIL
}

\author{
André Felipe Hess ${ }^{1 *}$, Táscilla Loiola ${ }^{2}$, Isadora de Arruda Souza ${ }^{1}$, Myrcia Minatti $^{3}$, Pollyni Ricken ${ }^{3}$, Geedre \\ Adriano Borsoi ${ }^{1}$ \\ ${ }^{1 *}$ State University of Santa Catarina, Department of Forestry, Lages, Santa Catarina, Brazil - hessandre@yahoo.com.br; \\ isa_arruda17@hotmail.com; geedreb@gmail.com \\ ${ }^{2}$ Federal University of Santa Maria, Graduate Program in Forestry, Santa Maria, Rio Grande do Sul, Brazil - tascillaloiola@gmail.com \\ ${ }^{3}$ Federal University of Parana, Graduate Program in Forest Engineering, Curitiba, Paraná, Brazil - myrciaminatti@ gmail.com; \\ pollyni7@hotmail.com
}

Received for publication: 25/09/2017 - Accepted for publication: 03/04/2018

\begin{abstract}
Forest management is the legal instrument to propose interventions and conservation of tree species in natural forests; it is a requirement for the management of commercial forest plantations. Considering as objective the conservation with sustainable management and knowledge of the increment rates in forests with Araucaria angustifolia, growth models were fitted with the measures of ring increment data of 587 trees, covering all distribution diameter classes, in four sites in southern Brazil. These fitted models showed the minimum cutting diameter of $40 \mathrm{~cm}$ for about 20 years (maximum annual increment in volume), cutting diameter of $55 \mathrm{~cm}$ in 37 years (maximum annual mean volume increment) and cutting cycle of 2 to 22.5 years for the diameter classes. The current increment rates in these diameter classes showed the need for approximately 20 years for the species to reach the minimum logging diameter. The lower growth rate in smaller diameter classes indicates that the species requires more time to reach the minimum cutting diameter, which is detrimental to the forest structure. The growth rate variability must be considered in the management of forests with A. angustifolia. The results showed the need and viability of sustainable silvicultural interventions to preserve forest diametric structures; otherwise the forest could compromise the development of larger trees.
\end{abstract}

Keywords: Growth, forest production, araucaria forest.

\section{Resumen}

Manejo forestal para la conservación de Araucaria angustifolia en el sur de Brasil. El manejo forestal es el instrumento legal para proponer intervenciones y conservación de especies en bosques naturales, siendo un requisito para la ordenación de la producción forestal. Con el objetivo de promover la conservación con gestión sostenible y conocer las tasas de incremento de bosques con Araucaria angustifolia, se ajustaron modelos de crecimiento con las medidas del incremento de anillos obtenidos de tarugos en 587 árboles, cubriendo la distribución de las clases de diámetro en cuatro sitios del sur de Brasil. El ajuste demostró: diámetro mínimo de corte de $40 \mathrm{~cm}$ alrededor de 20 años (máximo incremento corriente anual en volumen), diámetro límite de corte de $55 \mathrm{~cm}$ en 37 años (máximo incremento medio anual en volumen) y ciclo de corte de 2 a 22,5 años entre las clases de diámetro. La dinámica actual de la tasa de incremento entre las clases de diámetro mostró la necesidad de aproximadamente 20 años para que la especie alcance el diámetro mínimo de corte. La tasa de crecimiento menor en las clases diamétricas más pequeñas indica que la especie requiere más tiempo para alcanzar el diámetro mínimo de corte, que es perjudicial a la estructura del bosque. Los resultados sugieren que el manejo forestal en bosques de araucaria debería considerar la variabilidad de las tasas de crecimiento. Además, los resultados demuestran la viabilidad y necesidad de una intervención silvícola sostenible para conservar la estructura diamétrica, de lo contrario el bosque podría comprometer el desarrollo de una estructura con árboles de mayor dimensión.

Palabras-clave: Crecimiento, producción forestal, bosque de araucaria.

\section{INTRODUCTION}

The Mixed Ombrophilous Forest of the Atlantic Forest biome is characterized by the presence of Araucaria angustifolia (Bertol.) Kuntze trees (KERSTEN et al., 2015). These trees underwent an uncontrolled exploitation; thus, Brazilian federal laws prohibited its exploitation for wood or forest managements (BRAZIL, 2006; 2008; MMA, 2008), considering that the non-intervention of humans is a form of preserving their remnants.

However, the prohibitive legislation does not guarantee its conservation and genetic variability does not occur, because intervention is necessary and renovation in individuals (STEFENON et al., 2008). Since no cutting

FLORESTA, Curitiba, PR, v. 48, n. 3, p. 373-382, jul/set. 2018

Hess. A.F. et.al.

ISSN eletrônico 1982-4688 
of trees occurs nowadays, crossing occurs between the same trees; despite the formation, growth and crossing of new trees increases the evolutionary potential of the species by increasing their ability to adapt to environmental changes.

Therefore, forest managements must consider the intervention intensity, and the cycle between interventions (cutting cycle) that can be made effective for the sustainability, contributing to the dynamics of forest structure, growth rates, regeneration, and production. Information on the growth of trees is essential to predict their production and elaborate forest management plans, since their growth can vary within the same species; this variability is attributed to combined factors that may have temporal and spatial variation (EASDALE et al., 2007).

Growth models based on ring analysis (BRIENEN, ZUDEIMA, 2007) can be used to acquire direct results of tree age and growth rate throughout its life cycle by retrospective analysis. The growth rate of a species can give a general representation of its growth dynamics at certain conditions (climate, hydrology, soil, and successional stages) (SCHONGÄRT, 2008). Growth models can be easily determined by analyzing ring growths for different conditions (SCHÖNGART et al., 2005). These models and their analysis are essential for the development of a sustainable management and conservation of A. angustifolia.

This study considered the lack of sustainable management proposals for the conservation of the diametric structure of natural and unmanaged remnants of A. angustifolia. These proposals can be based on information on the growth variability by diameter classes of the species in its natural environment. Thus, this study investigated if the lack silvicultural intervention in the forest is enough to guarantee its conservation, and if silvicultural intervention based on growth differences between diameter classes, considering the trajectory of the tree diameter increment, is necessary for forest managements, evaluation of current structural characteristics, and prediction of subsequent structures.

Thus, the objectives of this study were to model the growth of A. angustifolia; and provide information on the biological rotation point of the species and cutting cycle for each diameter class based on the trajectory of individual increase, thus demonstrating the current growth conditions and the need for silvicultural interventions for the development of the diametric forest structure.

\section{MATERIAL AND METHODS}

\section{Characteristics of the study area and data collection}

The study was conducted in areas with occurrence of forests with Araucaria angustifolia trees (IBGE, 2012) in the state of Santa Catarina, southern Brazil. Samples were collected from 587 trees, covering all diametric distribution classes, in four sites with two sampling units per site (Table 2). The number of trees in the sites was 155 in São Joaquim (SJQ), 156 in Urupema (URU), 155 in Painel (PNL), and 121 in Lages (LAG). According to the Köppen classification, the climate of the regions is $\mathrm{Cfb}$, temperate, constantly humid, without dry season (ALVARES et al., 2013), with similar environmental variables (Table 1).

Table 1. Study sites and environmental variables of araucaria forest in Southern Brazil.

Cuadro 1. Sitios de estudio y variables ambientales del bosque de araucaria en el sur de Brasil.

\begin{tabular}{lccccc}
\hline \multirow{2}{*}{ Site } & Coordinates & $\begin{array}{c}\text { Altitude } \\
(\mathbf{m})\end{array}$ & $\begin{array}{c}\text { Everage annual } \\
\text { temperature }\left({ }^{\circ} \mathbf{C}\right)\end{array}$ & Precipitation (mm) & $\begin{array}{c}\text { Sample } \\
\text { area (ha) }\end{array}$ \\
\cline { 3 - 6 } & & 1,166 & 14.0 & 1,740 & 5.9 \\
SJQ & $28^{\circ} 15^{\prime}, \mathrm{S}-49^{\circ} 47^{\prime} \mathrm{W}$ & 1,259 & 13.7 & 1,722 & 5.5 \\
URU & $27^{\circ} 57^{\prime} \mathrm{S}-49^{\circ} 53^{\prime} \mathrm{W}$ & 1,123 & 15.3 & 1,543 & 3.5 \\
PNL & $27^{\circ} 58^{\prime} \mathrm{S}-50^{\circ} 06^{\prime} \mathrm{W}$ & 15.2 & 1,684 & 1.4 \\
LAG & $27^{\circ} 49^{\prime} \mathrm{S}-50^{\circ} 06^{\prime} \mathrm{W}$ & 987 & $\mathrm{~W}$ &
\end{tabular}

In which: SJQ, URU, PNL, LAG: São Joaquim, Urupema, Painel and Lages; S: south latitude; O: west longitude.

The forest structures were characterized by predominance of A. angustifolia trees, presenting distribution curves in the J-inverted form (HESS et al., 2010, HESS et al., 2014), with minimum diameter at breast height (d) of $10 \mathrm{~cm}$ (LAG), maximum of $127.6 \mathrm{~cm}$ (SJQ), and mean of 30 to $60 \mathrm{~cm}$. The forests had low regeneration rates for this species, and low number of trees in the smallest diameter classes, which can affect the development and maintenance of diametric structure. The structure in J-inverted form allows the application of management based on the Liocourt quotient to plan silvicultural interventions in the forest.

Diametric increment rates can show the A. angustifolia growth, denoting the viability and potential of this species for commercial use, reforestation plantations, and managing in forest remnants. However, the growth rate of araucaria trees gradually decreases until stagnation due to the lack of management in recent decades and competition between trees, as seen in the SJQ, PNL and LAG sites. 
Table 2. Diameter structure and mean annual increment in diameter of Araucaria angustifolia at study sites in Southern Brazil (n:587).

Cuadro 2. Estructura diamétrica y el incremento promedio en diámetro de Araucaria angustifolia en los sitios de estudio en el sur de Brasil (n: 587).

\begin{tabular}{ccccc}
\hline \multirow{2}{*}{ Site } & Statistic & \multicolumn{3}{c}{ Variable } \\
\cline { 3 - 5 } & Mean & $\mathbf{d}(\mathbf{c m})$ & $\mathbf{h}(\mathbf{m})$ & MAI $(\mathbf{c m} / \mathbf{y e a r})$ \\
\hline \multirow{3}{*}{ SJQ } & 62.8 & 16.8 & 0.34 \\
& Maximum & 127.6 & 26.1 & 2.392 \\
& Minimum & 23.5 & 11.5 & 0.036 \\
& $\sigma$ & 4.3 & 4.4 & 0.47 \\
\hline \multirow{3}{*}{ URU } & Mean & 46.3 & 15.7 & 0.903 \\
& Maximum & 89.4 & 23 & 4.798 \\
& Minimum & 18.8 & 8.8 & 0.069 \\
PNL & $\sigma$ & 7.2 & 7.5 & 0.50 \\
& Mean & 49.5 & 16.5 & 0.686 \\
& Maximum & 86.6 & 22.6 & 3.664 \\
& Minimum & 23.6 & 11.0 & 0.068 \\
& $\sigma$ & 1.8 & 4.9 & 0.71 \\
\hline \multirow{3}{*}{ LAG } & Mean & 32.5 & 13.9 & 0.57 \\
& Maximum & 87.6 & 20.3 & 0.99 \\
& Minimum & 10.0 & 6.6 & 0.18 \\
& $\sigma$ & 17.3 & 3.6 & 0.17 \\
\hline
\end{tabular}

In which: SJQ, URU, PNL, LAG: São Joaquim, Urupema, Painel and Lages; d: diameter at breast height (cm); h: height (m); MAI: mean annual increment in diameter (cm/year); $\sigma$ : standard deviation.

A. angustifolia species was chosen for this study because of its historical importance regarding the production of high-value wood, extraction of edible seeds, visibility of the growth rings (MATTOS et al., 2011), dominance in the forest, lack of information on its characteristics, and its potential for sustainable management, with a scientific basis.

Growth assessment, cutting cycle, statistical analysis and conservation of forest structure

Two increment rolls were extracted (non-destructive sampling method) from each tree perpendicular to the d (ASMANN, 1970). These rolls were glued on wooden supports, polished and their rings were marked. The tree age was obtained by counting the rings and the width between them, with determination of the annual increase in diameter (d), using a digital measuring device (Lintab-6) with precision of $0.0001 \mathrm{~mm}$, the Time Series Analyzes software (TSAP - Win) (Rinn Tech, 2010), and the cross-dating procedure (SCHÖNGART et al., 2005).

The incremental rates from bark to core were measured. The accumulated increment forms the growth curves of the diameters. The mean accumulated diameter growth curve describes the relationship between the tree age and diameter (SCHÖNGART, 2008). The time for the tree to reach the minimum logging diameter (MLD) and the diameter cutting limit (DCL) were determined considering the accumulated diameter growth curve of the tree. Thus, the modified Backman function was fitted to each study site using the correlation between tree age and annual diameter increment. MLD was obtained using the maximum current annual increment (CAI) and the DCL, by crossing the CAI curves and MAI data. Therefore, the cut the tree must be between those two points (SCHÖNGART, 2008) that describe the maximum values of the two measured increments, given by:

$$
\mathrm{d}=\mathrm{e}^{\beta_{1} * \ln \mathrm{t}_{1,3}+\beta_{2} * \ln ^{2} \mathrm{t}_{1,3}}
$$

In which: $\mathrm{d}$ : diameter at breast height; $\ln \mathrm{t}_{1.3}$ : neperian logarithm of the age of the increment rolls collected at height of $1.3 \mathrm{~cm}$; and $\beta_{\mathrm{s}}$ : coefficients of the model.

The diameter at breast height data of each age was used to obtained the height with the hypsometric function of Stofells as modified by Silveira et. al. (2018):

$$
\mathrm{h}=\mathrm{e}^{\beta_{0}+\beta_{1} * \ln \mathrm{d}}
$$

In which: h: height (m); ln d: neperian logarithm of the diameter at breast height; and $\beta_{\mathrm{s}}$ : coefficients of the model.

FLORESTA, Curitiba, PR, v. 48, n. 3, p. 373-382, jul/set. 2018

Hess. A.F. et.al.

ISSN eletrônico 1982-4688

DOI: $10.5380 /$ rf.v48 i3.55452 
Therefore, these equations give the tree age, the corresponding $\mathrm{d}$ (Equation 1), and tree height (Equation 2). The accumulated growth in volume $\left(\mathrm{V}_{\mathrm{t}}\right)$, current annual increment in volume $\left(\mathrm{CAI}_{\mathrm{V}}\right)$, and mean annual increment in volume $\left(\mathrm{MAI}_{\mathrm{V}}\right)$ were obtained for each tree age using the equations:

$$
\begin{aligned}
& \mathrm{V}_{\mathrm{t}}=\left(\frac{\pi * \mathrm{~d}_{\mathrm{t}}{ }^{2}}{40000}\right) * \mathrm{~h}_{\mathrm{t}} * \mathrm{f} \\
& \mathrm{CAI}_{\mathrm{V}}=\mathrm{V}_{(\mathrm{t}+1)}-\mathrm{V}_{\mathrm{t}} \\
& \mathrm{MAI}_{\mathrm{V}}=\frac{\mathrm{V}_{\mathrm{t}}}{\mathrm{t}}
\end{aligned}
$$

In which: $\mathrm{V}_{\mathrm{t}}$ : volume at age $\mathrm{t} ; \mathrm{d}_{\mathrm{t}}$ : diameter at breast height at age $\mathrm{t} ; \mathrm{h}_{\mathrm{t}}$ : tree height at age $\mathrm{t}$; $\mathrm{f}$ : conversion factor (0.65) (JUNIOR et al., 2015); CAIv: current annual increment in volume; MAIv: mean annual increment in volume; $\mathrm{V}_{(\mathrm{t}+1)}$ : volume at one year after age $\mathrm{t}$.

After the calculation of growth in volume, the criteria for sustainable management for conservation of the diametric structure in A. angustifolia forests were determined. The age-diameter relationship was considered in the calculation to indicate the growth variability and time to reach MLD. The cutting cycle (CC) was calculated according to Schöngart (2008), using the annual diameter increases in the ring width for each class and site, and the required age in which each class reaches the MLD.

The cutting cycle period represents the time (years) that trees need to grow, according to their respective increase rate and class, to achieve the MLD, and the time to the classes to reach greater diameter from this MLD, while maintaining their diametric structure and respective cutting cycles, considering the interval of $10 \mathrm{~cm}$ between the classes, given by:

$$
\mathrm{CC}=\frac{\text { edad }_{\mathrm{MLD}}}{(\mathrm{MLD} \times 0.1)}
$$

Analyses and fitting were processed in the SAS 9.3 program. The fitted coefficient of determination and the standard error of the estimate were used to assess the accuracy of the models. The mean diameter increment of each class was the parameter that indicated the structural dynamics and the conditions due to the lack of management, applied to A. angustifolia forests. Thus, the current increase rates, and the capacity of the remnants to reach characteristics for future structure conservation-presence of old trees of larger diameters (old-growth forest) — were determined.

\section{RESULTS}

\section{Fitted function}

The fit of Equation 1 for the sites explained $72 \%$ to $98 \%$ of the variation $(P<0.0001)$, with standard error of the estimate of 0.4 to 0.61 . The coefficients found were b1: $1.85337, \mathrm{~b} 2:-0.20557$ for SJQ; b1: 1.73216 , b2: 0.19305 for URU; b1: 1.808 , b2: -0.21323 for PNL, and b1: 1.7122 , b2: -0.18345 for LAG. The hypsometric relationship function explained $94 \%$ of the variation $(P<0.0001)$, with coefficients of b0: 0.47067, b1: 0.6311 and standard error of the estimate of 0.1366 . The residues of the equations showed compliance with the regression conditioners. The use of fitted equations and volume growth model made possible to determine the management criteria for the species (Figures 1A, 1B and Figures 2C, 2D). The growth curves were generated by modeling the diameter-age and height-diameter relationships. 

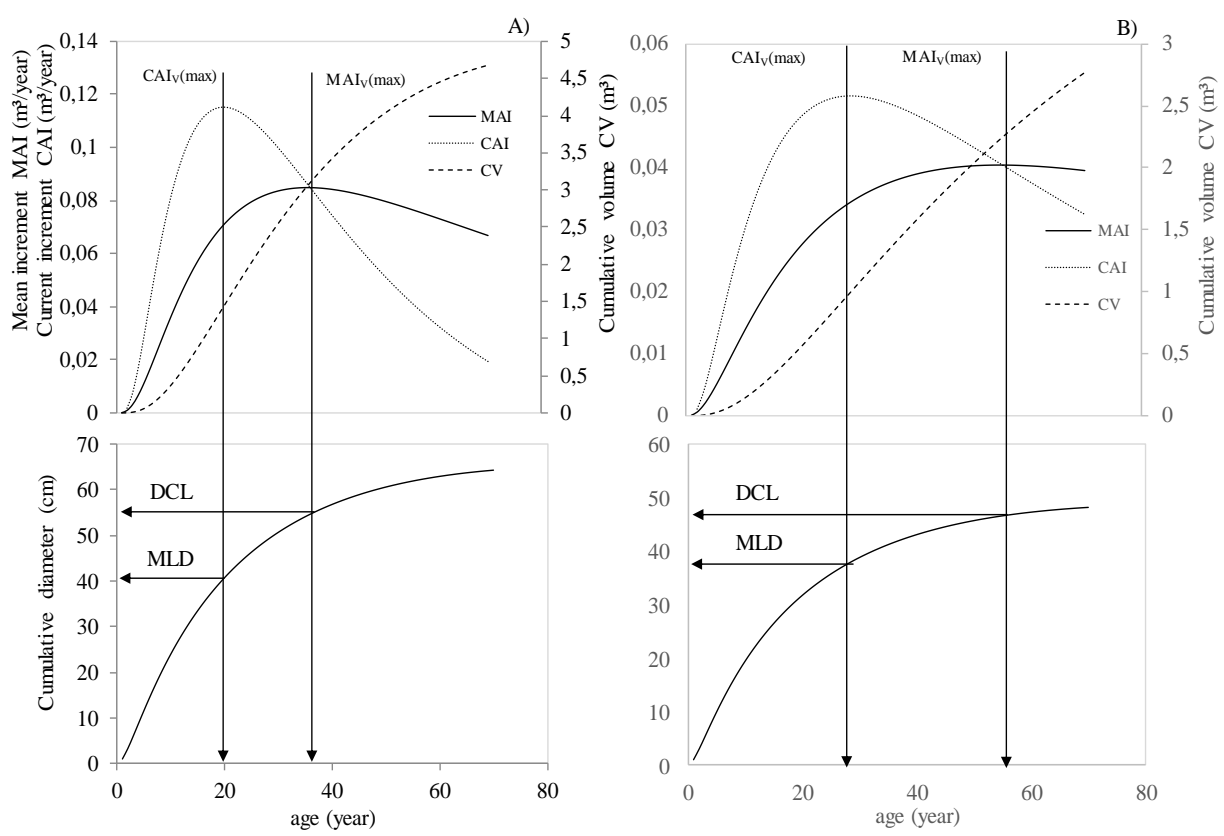

Figure 1. Growth in volume - accumulated volume (CV), current annual increment in volume (CAIv), and mean annual increment in volume (MAIV) - for Araucaria angustifolia trees in São Joaquim (A) and Urupema (B) as a function of age, indicating the trees' minimum logging diameter (MLD) and diameter cutting limit (DCL).

Figura 1. Crecimiento en volumen (VA) para la especie Araucaria angustifolia, incremento corriente anual $\left(I_{C}\right)$, incremento medio anual (IMAv) y su relación con el crecimiento en diámetro en función de la edad, indicando el DMC (diámetro mínimo de corte) y DLC (diámetro límite de corte); A) SJQ: São Joaquim; B) URU: Urupema.

The age at maximum current increment in volume (CAIvmax), minimum logging diameter (MLD), maximum mean annual increment in volume (MAIvmax), and the diameter cutting limit (DCL) were determined based on the diameter-age relationship of the trees. According to the growth rates, the $40 \mathrm{~cm}$ MLD determined for the intervention occurs at ages of 20 to 33 years, denoting that silvicultural intervention at this age is important for the conservation of the diametric structure of this species, and its sustainable management. The point of biological rotation (intersection of the curves CAIvmax and MAIvmax) occurs when the trees reach $55 \mathrm{~cm}$ in diameter, defining an DCL of 37 (SJQ) 56 (URU), 29 (PNL), and 39 (LAG) years. The results show the ideal period for the cutting of these trees, which was different for each site based on their increment rates. 

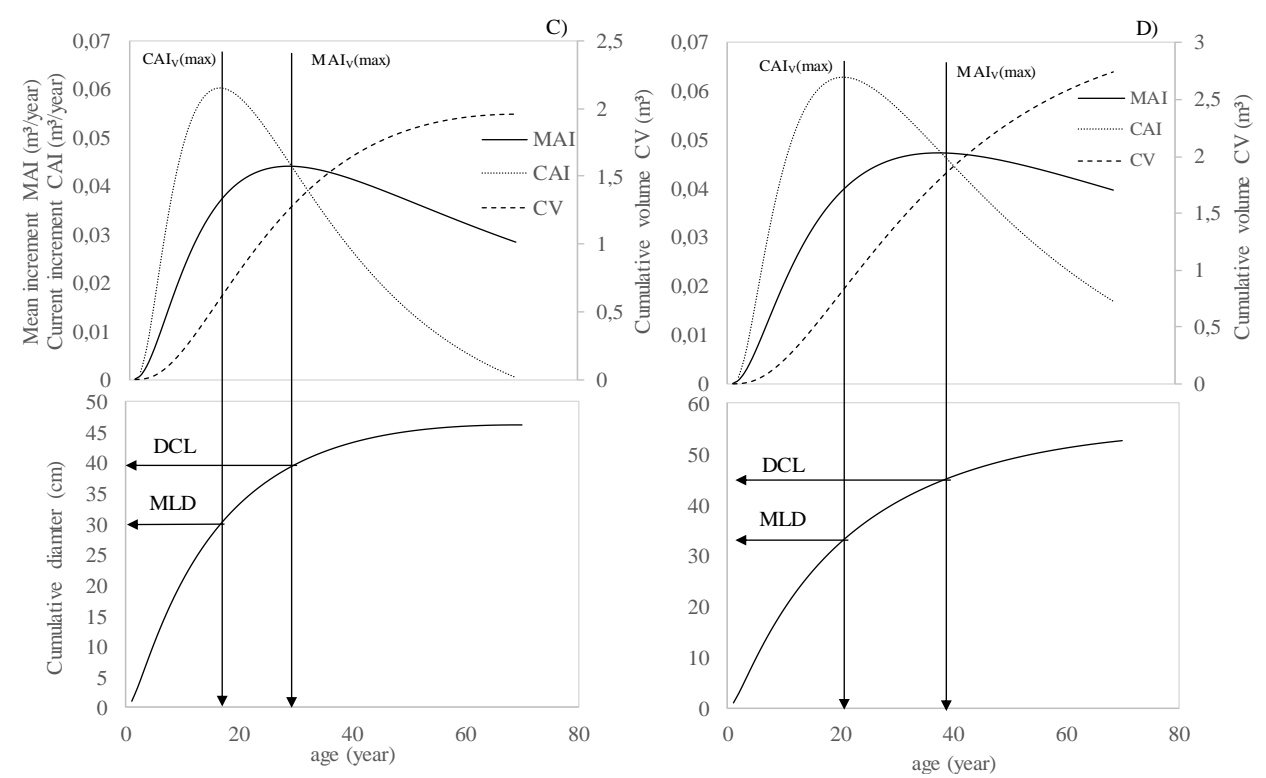

Figure 2. Growth in volume - accumulated volume (CV), current annual increment in volume (CAIV), and mean annual increment in volume (MAIV) - for Araucaria angustifolia trees in Painel (C) and Lages (D) as a function of age, indicating the trees' minimum logging diameter (MLD) and diameter cutting limit (DCL).

Figura 2. Crecimiento en volumen (VA) para la especie Araucaria angustifolia, incremento corriente anual $\left(I_{A} A_{v}\right)$, incremento medio anual (IMAv) y su relación con el crecimiento en diámetro en función de la edad, indicando el DMC (diámetro mínimo de corte) y DLC (diámetro límite de corte); C) PNL: Painel; D) LAG: Lages.

Therefore, the trees must be harvested between the $\mathrm{CAI}_{\mathrm{V}}(\max )$ and $\mathrm{MAI}_{\mathrm{V}}(\max )$ to obtain an optimal volume production. However, to obtain woods with larger diameters the correct is cut when maximizing the mean diameter increment. Cutting before $\mathrm{CAI}_{\mathrm{V}}(\max )$ and after the $\mathrm{MAI}_{\mathrm{v}}(\max )$ result in inefficient use of the growth potential of the species, since the trees will not have reached, or passed through, their optimum phase of growth. MLD is determined by the diameter in $\mathrm{CAI}_{\mathrm{V}}(\max )$, and the DCL is defined by the intersection of the $\mathrm{CAI}_{\mathrm{V}}(\max )$ and $\mathrm{MAI}_{\mathrm{v}}(\max )$ curves and can be derived from the diameter-age relationship (SCHÖNGART, 2008).

Although the trees were of same species, they had different diameter increment rates. This difference is connected to biotic and abiotic factors in the sites, and competition between trees. Moreover, specific growth characteristic of each site must be considered when carrying out silvicultural interventions; thus, it is not possible to adopt a standard management for all areas of occurrence of the species.

Trees in SJQ, PNL and LAG reached faster the limit cutting diameter after the last intervention. This shows the importance of forest management for their conservation. However, a new intervention is necessary after a certain period (Table 3), because trees of the smallest diameter classes have lower growth rates, which compromises the forest structure.

According to the cutting cycle by diameter class (Table 3), trees of the smallest diameter classes need longer periods to reach the MLD and longer cycle period for new interventions and replacement of trees. The lower increment rates of the smallest diameter classes denote that the growth increment of the trees can stabilize and compromise the development forest structures with larger trees, even after a silvicultural intervention. This low increment is characteristic of natural forests, or the result of competition between trees, and shows that this is not adequate to the structural conservation of the forest, and the need for silvicultural intervention.

URU and PNL had the highest increment rates in the $20 \mathrm{~cm}$ diameter class. All the sites showed lower growth rates in the 10-cm diameter class, compromising the forest structure development, because of the slower entry of trees of other classes. The diameter increment increased in intermediate classes and decreased with increasing diameter in all sites. Thus, the greater the increment in diameter, the lower the cutting cycle and the period between interventions. The results showed a characteristic pattern of natural forests, due to the lack of interventions (management) in the last 40 years in forests with A. angustifolia in southern Brazil.

The increment rates found were determined by the averages of all years measured in the rolls, therefore, trees with the largest diameters had higher averages. However, the average annual growth rate in the last 10 years in the best sites was $0.15 \mathrm{~cm}$ to $0.5 \mathrm{~cm}$. 
Table 3. Increment in diameter, cutting cycle and diametric-temporal structure of araucaria forest in its occurrence area in Southern Brazil.

Cuadro 3. Incremento en diámetro, ciclo de corte y estructura diametral-temporal del bosque de araucaria en su área de ocurrencia en el sur de Brasil.

\begin{tabular}{cccccccccc}
\hline \multirow{2}{*}{ Site } & \multirow{2}{*}{ Dend.Var. } & \multicolumn{9}{c}{ Diameter class (cm) } \\
\cline { 3 - 10 } & & $\mathbf{1 0}$ & $\mathbf{2 0}$ & $\mathbf{3 0}$ & $\mathbf{4 0}$ & $\mathbf{5 0}$ & $\mathbf{6 0}$ & $\mathbf{7 0}$ \\
\hline \multirow{2}{*}{ LAG } & MAI & 0.41 & 0.62 & 0.59 & 1.25 & 0.58 & 0.78 & 0.6 \\
& MLDa & 74 & 33 & 17 & 32 & 17 & 28 & 49 \\
& CC & 18.5 & 8.25 & 4.25 & 8 & 4.25 & 7 & 12.25 \\
\hline \multirow{3}{*}{ SJQ } & MAI & 0.33 & 0.45 & 0.59 & 2 & 0.53 & 0.41 & 0.34 \\
& MLDa & 91 & 45 & 17 & 20 & 18 & 48 & 88 \\
& CC & 22.75 & 11.25 & 4.25 & 5 & 4.5 & 12 & 22 \\
\hline \multirow{3}{*}{ URU } & MAI & 0.41 & 0.78 & 0.9 & 1.21 & 1.05 & 0.93 & 0.89 \\
& MLDa & 74 & 26 & 12 & 33 & 9 & 21 & 33 \\
& CC & 18.5 & 6.5 & 3 & 8.25 & 2.25 & 5.25 & 8.25 \\
\hline \multirow{3}{*}{ PNL } & MAI & 0.41 & 0.94 & 0.74 & 1.37 & 0.68 & 0.75 & 0.69 \\
& MLDa & 74 & 22 & 14 & 29 & 14 & 26 & 43 \\
& CC & 18.5 & 5.5 & 3.5 & 7.25 & 3.5 & 6.5 & 10.75 \\
\hline
\end{tabular}

In which: Dend.Var.: dendrometric variables; LAG: Lages; SJQ: São Joaquim; URU: Urupema; PNL: Painel; MAI: mean annual increment per diameter class in (cm); MLDa: (minimum logging diameter) number of years required to reach the $40 \mathrm{~cm}$ of MLD; and this to achieve the largest diameter classes; CC: cutting cycle in years.

The cutting cycle is dependent on the growth increment stagnation and competition between trees. For example, with a mean annual increment diameter of $0.33 \mathrm{~cm}$, it would take 91 years for the tree to reach the minimum logging diameter (MLD), with a cutting cycle of 23 years.

Trees of the smallest diameter classes grow more slowly than those of largest classes in the forest with no silvicultural intervention. The diameter growth rate increases between the diametric classes until reaching the maximum increment and then this increment decreases. The larger the increment in diameter, the shorter the time between classes and the cutting cycle. Thus, trees of smaller diameter take longer to reach the minimum logging diameter of $40 \mathrm{~cm}$, slowing the growth processes that occurs in native forests with no intervention.

The highest mean annual increment rates were found in the largest diameter classes $-2 \mathrm{~cm}$ in the $40 \mathrm{~cm}$ class, $1.05 \mathrm{~cm}$ in the $50 \mathrm{~cm}$ class, and 0.93 in the $60 \mathrm{~cm}$ class. Thus, the last intervention (40 years before the experiment) opened spaces and generated better conditions for the mean diameter annual increment. This explains the importance of silvicultural interventions and forest management to form a forest structure with characteristics of primary forest.

The fitted growth functions show the growth potential and viability of forest management, and the need of this intervention to maintain the diametric structure and the species spatial and temporal dynamics in southern Brazil. Forests with appropriate management can rapidly generate trees with minimum logging diameter of $40 \mathrm{~cm}$, which is similar to the growth of conifers introduced in the region. Therefore, forests managing for the conservation of this species would recovery its historical importance in the landscape; and stimulate the cultivation and interest in maintaining forests remnants with A. angustifolia.

\section{DISCUSSION}

The evaluation of dendrometric variables can generate predictions based on the existing conditions for the diameter increment of the species, since the structure and dynamics of the forest are dependent on its age, site, and competition between trees. Thus, managements to conserve a forest structure require information on its growth rates, biological rotation point, and cutting cycle for interventions. This information makes possible to understand the need for silvicultural interventions to quantify growth processes and maintain the diametrical structure of the forest and its conservation.

The increment in the studied sites showed the need for intervention in the forests, since many diameter classes reached growth stagnation point, and need for better growth of the lower diameter classes. The growth rate and structural analysis of the A. angustifolia in natural forests denoted the need for establishing specific management criteria for sites in which this species occurs.

The objective of this study is not to propose a management plan for the species based on increment rates of the diameter classes, since this plan can underestimate growth rates and requires a long observation period (SCHÖNGART, 2008). However, these results are important to complete growth models and for

FLORESTA, Curitiba, PR, v. 48, n. 3, p. 373-382, jul/set. 2018

Hess. A.F. et.al.

ISSN eletrônico 1982-4688

DOI: $10.5380 /$ rf.v48 i3.55452 
the conservation of species in natural forests because the analysis of the growth rings (BRIENEN; ZUIDEMA, 2007) shows the real trajectory of the growth for harvesting trees in different site conditions.

The species showed lower growth rates in the smallest diameter classes in all study sites, and great growth rate variability and transition time between classes to the MLD. Although this characteristic is expected in unmanaged forests, it is not suitable for the conservation of the species since it hinders the diametric structure development.

Therefore, interventions for density reduction is important to guarantee the sustainability requirements of the forest structure, and to contribute to the development of the ecosystem. However, cutting cycles or rotation periods only guarantee the sustainable use of wood resources if the harvested species continue to reproduce (SCHÖNGART, 2008). Therefore, silvicultural interventions in the forest are necessary to reduce competition, stimulate regeneration and reproduction, and maintain the growth of the trees.

According to Hosokawa and Solter (1995), a rational use of forest is achieved by applying appropriate silvicultural techniques. Thus, the growth structure of forest species must be known, and the results of structural analysis are key for forest managing. Bauhus et al. (2009) stated that silvicultural systems used to maintain and restore old-growth forests can and must employ different approaches to manage their structural, spatial, and temporal complexities. Forest management and silvicultural systems can promote the developing and maintenance of the attributes of primary forests.

Silvicultural techniques stimulate tree growth and maintain structural characteristics of primary forest. Trees of lower diameter classes may have conditions to replace trees of larger diameter classes to guarantee the forest structure. Moreover, structural components that are related to tree size can be efficiently modified by density management.

However, A. angustifolia needs to be managed because this species shows stable or decreasing growth production over time, low or no appearance of new individuals, low increment rates, competition between trees, limited resource availability, and high mortality rates in unmanaged forests, indicating a tendency of disappearance of the species if no silvicultural intervention is carried out (BECKERT et al., 2014).

Therefore, a proposal of sustainable cutting of this species with the elimination of a few trees is needed to decrease increment rate variability and cutting cycle. Thus, forest management can have economic, environmental, and social sustainability, causing no imbalance on the ecosystem as the predatory exploitation of natural resources. This management encourages multiple uses of forest resources, improving the ecosystem regeneration, production, profitability, and cultural development.

The protection of $A$. angustifolia through the prohibition of its use and management devaluated this species, reduced the interest in forest conservation, decreased increment rates, and compromised the development of forests with A. angustifolia. This occurred in the study area, since the owners of the A. angustifolia forests cut naturally grown seedlings, reforest areas with Pinus sp. for private cellulose companies, promoting the devaluation of the A. angustifolia; contrastingly, the use of this species could result in better economic and social development of the region.

Conserving forest resources without management can compromise the development of diametric structures of forests with A. angustifolia and its succession, and the development of intrinsic tree shape variables and timber production. Therefore, silvicultural intervention is indicated as a measure of forest conservation to increase increment rates and maintain structures with characteristics of primary forests.

Information on increment rates is necessary to manage forests with the MLD (30 to $40 \mathrm{~cm}$ for a cutting cycle of 20 years) and DCL ( 40 to $55 \mathrm{~cm}$ in a cycle of 40 years) determined, since these rates are dependent on the site and density of each forest remnant. The information presented in this study can assist in proposals of changes on the current legislation to allow the rational use of this species with forest management to preserve the structure and increase interest in this species (MMA, 2017).

Silveira et al. (2018) proposed a simulation of management of araucaria forests with variation of the Liocourt's q quotient of 1.1, 1.3, and 1.5, remaining basal area of 10, 12, and $14 \mathrm{~m}^{2}$ ha-1 and cutting cycle of 20,25 and 30 years and concluded that the best scenario for the forest was the q of 1.5, basal area of 12 to 14 , and cutting cycle of 20 to 25 years, with removal of trees of larger diameters, maintaining trees with smaller diameters.

Sullivan and Sullivan (2016) analyzed the effects of thinning in Pinus contorta in North America and found that the mean diameter increment, cup volume, diversity and commercial volume were higher in lower density forest compared to medium to high density and not thinned forests; they concluded that the acceleration of forest succession to develop the final structural characteristics in younger forests can be achieved by silvicultural practices, such as thinning, and the average diameter growth rates, diversity, canopy volume, and multilayered canopy are better in low density forests, followed by medium, high, without thinning, and old-growth forests.

Forestry and most silvicultural interventions are not intended to produce plants with characteristics found in old-growth forests, but to favor some structures and tree species based on their economic value, maintaining the 
growth rates and management efficiency (BAUHUS et al., 2009). Harvest of forests must be continuous; it is needed for the development of the structural attributes of the primary forests in secondary forests (SULLIVAN; SULLIVAN, 2016).

The trajectory of individual growth dynamics is a tool that can be used to indicate planned interventions in forest management, since the diametric structure requires future replacement by larger trees, because naturally those that now occupy space in the forest will reach the mortality.

The growth curve indicates that managed forests can reach MDL and DCL in fewer years than those with no management. This indicates that the trees of greater diameter have reached their maximum capacity and the point of biological rotation, while others of smaller diameters are trees with stagnant growth.

\section{CONCLUSIONS}

- The forest growth model for forests with Araucaria angustifolia requires a longer period of interventions for this species to reach the determined MDL and DCL. This growth model indicates the point of biological rotation for dendrometric and production variables, and the cutting cycle variability according to the growth in each diameter class and site.

- The absence of management of a forest is not a guarantee of its conservation over time since it compromises the continuum development of the diametric structures of trees of greater diameter and that migrate faster and with less variability of the increment between classes over time. The evaluation of the current structure based on the individual trajectory of the increment for the different diameter classes can assist in the prediction of the development of the forest structure.

- The individual trajectory of the diameter increment, height, volume, and individual diameter development of the trees of each site can be used to determine characteristics that affects the current development and the future possibilities of the forest to grow in the same conditions.

\section{ACKNOWLEDGEMENTS}

The authors thank the National Council of Scientific and Technological Development (CNPq) for the financial support for this project (Universal 14/2013); the State University of Santa Catarina; the Foundation for Support of State Research of Santa Catarina (FAPESC; 2017TR639); and the owners of the forests with Araucaria angustifolia for the study area.

\section{REFERENCES}

ALVARES, C. A.; STAPE, J. L.; SENTELHAS, P. C.; Gonçalves, J. L. M.; PAROVEK, G. Köppen's climate classification map for Brazil. Meteorologische Zeitschrift Stuttgart, v. 22, p. 711 - 728, 2013.

ASSMANN, E. The principles of forest yield study. Oxford: Pergamon, 1970. 506 p.

BAUHUS, J.; PUETMAN, K.; MESSIER, C. Silviculture for old-growth attributes. Forest Ecology and Management, Amsterdan, v. 258, p. 525 - 537, 2009.

BECKERT, S. M.; ROSOT, M. A. D.; ROSOT, N. C. Crescimento e dinâmica de Araucaria angustifolia (Bert.) O. Ktze. em fragmento de Floresta Ombrófila Mista. Scientia Forestalis, Piracicaba, v. 42, n. 102, p. 209 - 218 , 2014.

BRASIL. Decreto no 11428, 22 de dezembro de 2006. Dispõe sobre a utilização e proteção da vegetação native do Bioma Mata Atlântica, e dá outras providências. Diário Oficial [da República Federativa do Brasil], Brasília, p. 1, 2006.

BRASIL. Decreto n⿳ 6514, de 22 de junho de 2008. Dispõe sobre as infrações e sanções administrativas ao meio ambiente, estabelece o processo administrativo federal para apuração destas infrações, e dá outras providências. Diário Oficial [da República Federativa do Brasil], Brasília, p. 1, 2008.

BRIENEN, R. J. W.; ZUDEIMA, P. A. Incorporating persistent tree growth differences increases estimates of tropical timber yield. Frontier in Ecology and the Environment, Washington, v. 5, n. 6, p. 302 - 306, 2007.

EASDALE, T.A.; HEALEY, J.R.; GRAU, H.R.; MALIZIA, A. Tree life histories in a montane subtropical forest: species differ independently by shade-tolerance, turnover rate and substrate preference. Journal of Ecology, London, v. 95, p. 1234 - 1249, 2007.

FLORESTA, Curitiba, PR, v. 48, n. 3, p. 373-382, jul/set. 2018

Hess. A.F. et.al

ISSN eletrônico 1982-4688 
FAO (Food and Agriculture Organization of the United Nations, IT). 2007. State of the World's Forest. Consultado 25 mar. 2016. Disponible en: http://www.fao.org/forestry/site/sofolen

HESS A. F.; MINATTI, M.; FERRARI, L.; PINTRO, B. A. Manejo de floresta ombrófila mista pelo método de Liocourt, município de Painel, SC. Cerne, Lavras, v. 20, n. 4, p. 575 - 580, 2014.

HESS, A. F.; CALGAROTTO, A. R.; PINHEIRO, R.; WANGINIAK, T. C. R. Proposta de manejo de Araucaria angustifolia utilizando o quociente de Liocourt e análise de incremento, em propriedade rural no município de Lages, SC. Pesquisa Florestal Brasileira, Colombo, v. 30, n. 64, p. 337 - 345, 2010.

HOSOKAWA, R. T.; SOLTER, F. Manejo Florestal. Curitiba, Brasil. UFPR. 1995. 43 p.

IBGE (Instituto Brasileiro de Geografia e Estatística, BR). Manual técnico da vegetação brasileira: sistema fitogeográfico, inventário das formações florestais e campestres, técnicas de manejo de coleções botânicas, procedimentos para mapeamentos. Rio de Janeiro: IBGE - Diretoria de Geociências, 2012. 271 p. (Manuais Técnicos de Geociências, 1).

JUNIOR, L. T.; CARDOSO, D. J.; ROSOT, M. A. D.; GARRASTAZÚ, M. C.; OLIVEIRA, E. B. de; GOMES, J. B. V.; ARCE, J. E.; ROSOT, N. C.; FRANCISCON, L. Evolução da forma do tronco e do volume por sortimento em Araucaria angustifolia (Bert.) O. Ktze plantada em espaçamento amplo. Colombo: Embrapa Florestas, (Embrapa Florestas. Documentos 285). 54 p., 2015.

KERSTEN, R. A.; BORGO, M.; GALVÃO, F. Floresta Ombrófila Mista: aspectos fitogeográficos, ecológicos e métodos de estudo. In: FELFILI, J. M.; EISENLOHR, P. V.; MELO, M. M. R. F.; ANDRADE, L. A.; MEIRA, N. (eds.) Fitossociologia no Brasil: métodos e estudo de caso. Viçosa, Brasil. Editora UFV, v. 2, n. 1, p. 156 $182,2015$.

MATTOS, P. P.; BRAZ, E. M.; HESS, A. F.; SALIS, S. M. A dendrocronologia e o manejo florestal sustentável em florestas tropicais. Colombo: Embrapa Florestas; Corumbá: Embrapa Pantanal, (Embrapa Florestas. Documentos, 218); (Embrapa Pantanal. Documentos, 112). 37 p., 2011.

MMA. Ministério do Meio Ambiente. Ibama - Instituto Brasileiro do Meio Ambiente e dos Recursos Naturais Renováveis - Nota Técnica no. 01, 30/05/2017. Proposição Legislativa: projeto de lei - PL 6914, Brasília, 20p., 2017.

MMA. Ministério do Meio Ambiente. Instrução Normativa nº 6, de 23 de setembro de 2008. Reconhece espécies da flora brasileira ameaçadas de extinção e revoga a Portaria Normativa Ibama no 37- N, de 3 de abril de 1992. Diário Oficial [da República Federativa do Brasil], Brasília, nº 185, seção 1, p. 75, 2008.

RINN TECH. TSAP-WIN: Time series analysis and presentation dendrochronology and related applications. 2010. 2 p.

SCHÖNGART, J.; PIEDADE, M. T. F.; WITTMANN, F.; JUNK, W. J.; WORBES, M. Wood growth patterns of Macrolobium acaciifolim (Benth.) Benth. (Fabaceae) in Amazonian black-water floodplain forests. Oecologia, Australian, v. 145, p. 654 - 661, 2005.

SCHÖNGART J. Growth-Oriented Logging (GOL): a new concept towards sustainable forest management in Central Amazonian várzea floodplains. Forest Ecology and Management, Amsterdan, v. 256, p. 46 - 58, 2008.

SILVEIRA, A. C. da.; HESS, A. F.; SCHORR, L. P. B.; KREFTA, S. M.; SANTOS, D. V. dos.; FILHO, M. D. H. V.; ALVES, K. A.; COSTA, E. A.; STEPKA, T. F.; BORSOI, G. A. Management of Brazilian pine (Araucaria angustifolia (Bertol) Kuntze) based on the Liocourt model in a mixed ombrophilous forest in Southern Brazil. Australian Journal of Crop Science, Austrália, v. 12, n. 02, p. 311-317, 2018.

STEFENON, V. M.; GAILING, O.; FINKELDEY, R. Genetic structure and the conservation of genetic resources of Brazilian pine (Araucaria angustifolia). Forest Ecology and Management, Amsterdan, v. 255, p. 2718 - 2725 , 2008

SULLIVAN, T. P.; SULLIVAN, D. S. Acceleration of old-growth structural attributes in lodgepole pine forest: Tree growth and stand structure 25 years after thinning. Forest Ecology and Management, Amsterdan, v. 365, p. 96 - 106, 2016. 